\title{
О.Ю. Чертков
}

к.т.н., доц.

\section{В.О. Цегельний}

аспірант

\section{Д.С. Срмолович}

студ. буд. факульт., 6-й курс

Київський національний університет будівництва і архітектури, м. Київ

\section{ОСОБЛИВОСТІ ВИКОРИСТАННЯ ВІМ-ТЕХНОЛОГІї В ВІТЧИЗНЯНИХ КОМПАНІЯХ В УМОВАХ ВІДСУТНОСТІ НАЦІОНАЛЬНИХ СТАНДАРТІВ ІНФОРМАЦЙНОГО МОДЕЛЮВАННЯ БУДІВЕЛЬ- ВІМ}

\begin{abstract}
Анотація. Незважаючи на високі потенційні можливості ВІМ-технології (збільшення продуктивності пращі, поліпшення якості документованої інформащї, підтримка уніфікованого і узгодженого стилю роботи) далеко не всі учасники, що використовують методику інформаційного моделювання , досягають очікуваних результатів. Існують різні причини можливих невдач, але, мабуть, основною причиною є неадекватне розуміння суті інтегруючої роботи інформачійних систем і застосування ВIM-засобів.

Ключові слова: інформаційне моделювання, ВIM, ВІМ-стандарти, ВІМ-технологія, життєвий цикл, будівельний проект, проектування, моделювання, будівництво, експлуатація, документована інформація.
\end{abstract}

Вступ.

Ще не так давно був здійснений перехід "від кульманів до АВТОКАД", а весь проектний світ досить швидко і позитивно оцінив переваги використання векторної графіки. Сьогодні настав час чергових змін і вже зрозуміло, що цей час BIM. Незважаючи на високі потенційні можливості ВІМ-технології (збільшення продуктивності праці, поліпшення якості документованої інформації, підтримка уніфікованого і узгодженого стилю роботи) далеко не всі учасники, що використовують методику інформаційного моделювання , досягають очікуваних результатів.

BIM - (Building Information Modeling або Building Information Model - інформаційне моделювання будівлі або інформаційна модель будівлі) - це цифрове представлення фізичних і функціональних характеристик об'єкта, яке охоплює більш ніж просто геометрію будівлі.

ВIM враховує безліч факторів і інформацію про об'єкт, окремі його елементи (навіть деталі виробників), географію, дизайн та інші дані, в тому числі вплив його на навколишнє середовище і навпаки.

Всі ці дані поряд з техніко-економічними показниками і іншими характеристиками об'єкта формують таку інформаційну модель, в якій зміна одного параметра призводить до автоматичного перерахунку всіх інших.

BIM - це загальний ресурс знань для отримання інформації про об'єкт, служить основою для прийняття рішень протягом його життєвого циклу, який визначається як існуючий від самої ранньої концепції до знесення.

Основою взаємодії $€$ інформаційна модель об'єкта будівництва (ВIМ-модель), за допомогою якої відбувається комплексна взаємодія сторінучасниць на всіх стадіях життєвого циклу об'єкта.
ВIM дозволяє передавати віртуальну інформаційну модель від команди розробників (архітектори, ландшафтні архітектори, інженери, будівельники i т. д.) генпідряднику і субпідрядникам, а потім власникам або керуючим об'єкта. На практиці це виглядає так, наприклад проектувальник вніс якісь зміни до проекту, про це негайно дізнаються всі учасники, включаючи того, хто розраховує будівельний кошторис, і вносять свої корективи. У ВІМ-моделі легко можна зрозуміти, яка марка бетону використана для виготовлення тієї чи іншої колони або балки, якого вона типорозміру і навіть на якому підприємстві виготовлена. В результаті в одному місці складується вся інформація про будівлю. На об'ємній моделі наочно видно, які помилки і неточності були допущені. Ці неточності можна набагато швидше усунути, i, таким чином, процес проектування значно прискорюється.

Стандартизація. Гармонізація з міжнародними стандартами [3]. Легітимізація цифрової інформаційної моделі об'єктів.

В пострадянських країнах у 2014-2015 роках тема ВIM отримала настільки широке висвітлення, стільки раз представлялася, обговорювалася і дискутувалася, що можна говорити про "пробудження від сплячки", в той час коли в інших розвинених країнах напрацьовувався досвід і розроблялися свої національні документи типу ВІМ-стандартів або ВIM-посібників. В той же час, це "пробудження" не було таким швидким, як того хотілося б, тому що тільки зараз почалася консолідація професійної спільноти, зацікавленої в грамотному становленні нового середовища роботи і життя, де був би врахований і накопичений вже і національний, і міжнародний досвід, а всі учасники галузі - від освіти до експертизи - переходили б на нові рейки. [5] 


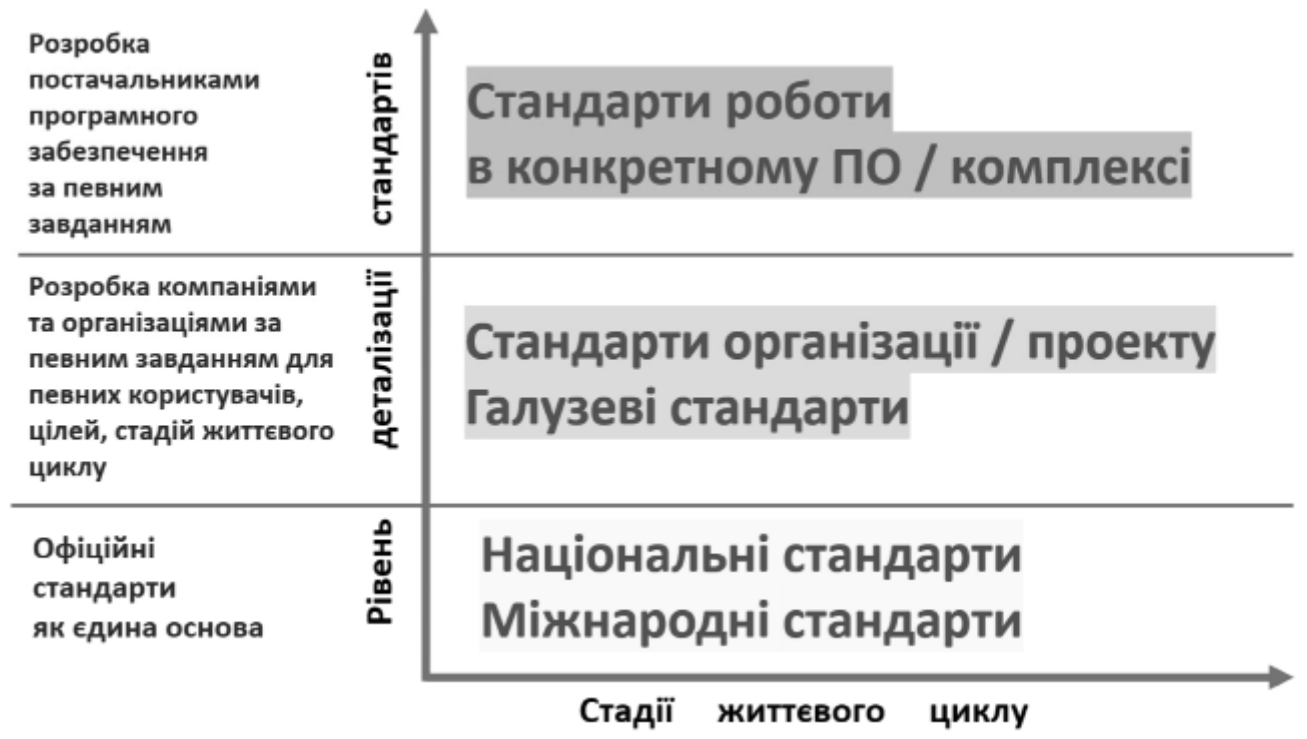

Рис. 1. Сфери застосування стандарту інформаційного моделювання

Але відсутність загальноприйнятого алгоритму переходу і роботи на BIM, різноманітність програмного забезпечення, іноді нерозуміння самої концепції технології, усвідомлення масштабності - адже порушується повний цикл будівництва та експлуатації - від задуму до знесення - лякає і змушує задуматися про ризики. На допомогу цьому, може прийти відкрите i прозоре обговорення всіма зацікавленими сторонами, організаціями, які на практиці займаються впровадженням ВІМ-технологій, в результаті якого можна буде забезпечити створення і впровадження на практиці ефективної системи нормативно-технічного забезпечення технологій інформаційного моделювання на вже існуючій базі міжнародних стандартів, зокрема:

a) формування єдиної основи для розробки стандартів інформаційного моделювання будівель i споруд:

- сприяння в розробці зрозумілих і багаторазово повторюваних виробничих процесів;

- забезпечення розробки міждержавних і національних стандартів, а також стандартів окремих проектів на єдиній основі;

- забезпечення розробки керівництв по роботі з програмними додатками на єдиній основі.

b) забезпечення можливості контролю стандартів інформаційного моделювання:

- забезпечення повноти стандартів на основі контрольного списку результатів робіт, управляючих впливів і вихідних даних;

- забезпечення подання обгрунтованих пояснень до необхідних результатів робіт;

- забезпечення здатності стандарту до розширюваності;

- підтримка можливості об'єднання і порівняння стандартів інформаційного моделювання.

c) забезпечення можливості перевірки відповідності стандартів інформаційного моделювання:

- забезпечення можливості перевірки відповідності стандартів основоположним принципам;

- забезпечення можливості перевірки відповідності практики застосування інформаційного моделювання стандартам;
- сприяння застосуванню офіційних положень договорів, що стосуються застосовуваних стандартів інформаційного моделювання - ISO/TS 12911:2012 Framework for building information modelling (BIM) guidance. - Моделювання інформаційне у будівництві. Основні положення по розробці стандартів інформаційного моделювання будівель і споруд. [3]

Тим більше, що стандарти BIM:

- орієнтуються на об'єктно-орієнтовані способи роботи [1] де інформація має більш пророблену структуру і можливість неодноразового використання;

- де формуються основні принципи встановлення технічних вимог до результатів робіт з інформаційного моделювання, які дозволяють розробляти стандарти з інформаційного моделювання міжнародного, національного рівня і для окремих проектів, а учасникам нових проектів - реалізовувати в своїй роботі практичні методики і плани інших учасників (див. Рис. 1).

Щоб не перетворити вирішення питання, щодо розробки нормативно-правових актів, покликаних легітимізувати цифрову інформаційну модель об'єкта для задач, які раніше розв'язувалися тільки на папері, в складну дилему, а також забезпечити законну можливість державному і муніципальному замовнику висувати вимоги про виконання проектів в технології ВIM наводимо схему: "Сфери застосування стандарту інформаційного моделювання" (див. рис 1) [3].

Знайомство $з$ цією схемою повинно надати впевненість ВIM-спільноті в тому, що чекання, коли в державі з'являться національні стандарти з інформаційного моделювання, може бути й продуктивним, якщо в цей час застосовувати міжнародні стандарти на цю ж тему, тим більш, що вони вже пройшли етапи випробувань і помилок. Підтвердженням тому є той факт, що окремі команди вже давно і впевнено працюють з ВIM, оптимізуючи процес роботи над проектом i, зокрема, істотно скорочуючи час внесення в нього змін. Особливо відчутно це в роботі тих бригад, які займаються супроводом проектів іноземних бюро.

Існують різні причини можливих невдач, але, мабуть, основною причиною $є$ неадекватне розумін- 
ня суті інтегруючої роботи інформаційних систем застосування ВІМ-засобів.

Необхідно розуміти, що процес проектування і розробки організаційно-технологічної документації будівництва на основі BIM-технології не може бути подібний до процесу приготування їжі по кулінарній книзі. Завжди слід бути готовим до нових труднощів, пов'язаних з освоєнням нової технології, послідовно долати ці труднощі і послідовно домагатися потрібних результатів.

Тенденції розвитку сучасних технологій взагалі, i, особливо ВIМ-технологій в будівництві, приводять до постійного зростання складності систем інформаційного моделювання.

Сучасні великі проекти, де застосовуються ВIM-технології характеризуються, як правило, такими особливостями:

- складність опису (досить велика кількість функцій, процесів, елементів даних і складні взаємозв'язки між ними), що вимагає ретельного моделювання і аналізу даних і процесів;

- наявність сукупності тісно взаємодіючих компонентів (підсистем), що мають свої локальні завдання і цілі функціонування (наприклад, традиційних додатків, пов'язаних з обробкою транзакцій і рішенням регламентних завдань, і додатків аналітичної обробки (підтримки прийняття рішень), що використовують нерегламентовані запити до даних великого обсягу);

- невміння застосовувати аналоги (або відсутність прямих аналогів) суттєво обмежує можливість використання будь-яких типових проектних рішень і прикладних систем;

- необхідність інтеграції існуючих і тих, що розробляються, додатків;

- функціонування в неоднорідному середовищі на декількох апаратних платформах;

- роз'єднаність і різнорідність окремих груп розробників за рівнем кваліфікації і традиціями, що склалися використання тих чи інших інструментальних засобів;

- істотна тимчасова протяжність проекту, обумовлена, з одного боку, обмеженими можливостями учасників інвестиційно-будівельних проектів, i, 3 іншого боку, масштабами комплексу будови і різним ступенем готовності окремих організацій-учасників будівництва до застосування (впровадження) інформаційного моделювання.

На кожній конференції можна почути про обов'язковість застосування технології на будівельному майданчику, активно ведуться розробки для інтеграції з експлуатуючими організаціями. Зростає кількість презентацій з використанням хмар точок і лазерного сканування. Однак аудиторія семінарів уважно все вислуховує, а потім повертається на робочі місця і продовжує працювати як раніше. Незважаючи на очевидну користь, глобальність нових підходів і необхідність переформатувати професійну свідомість відразу всього колективу веде до того, що проектувальники і керівники досі сумніваються: "А чи варто щось міняти?". [2]

Якщо ще недавно термін ВIM асоціювався виключно з 3х-мірним проектуванням (моделюванням), практично ототожнювався 3 ним, то вже сучасне розуміння розширює підхід - зараз це 3D модель плюс додаткова інформація (метадані), яка дозволяє на зовсім іншому рівні вибудувати процеси, пов'язані 3 супроводом всього інвестиційно-будівельного проекту протягом його життєвого циклу.

Для успішної реалізації інвестиційно-будівельного проекту комплекс будов (об'єкт моделювання) повинен бути, перш за все, адекватно описаний, повинні бути побудовані повні і несуперечливі функціональні та інформаційні моделі процесів та робот. Накопичений в Україні до теперішнього часу досвід інформаційного моделювання показує, що це логічна, складна, трудомістка і тривала за часом робота вимагає високої кваліфікації задіяних в ній фахівців. Однак до недавнього часу проектування інформаційних моделей виконувалося, в основному, на інтуїтивному рівні із застосуванням неформалізованих методів, заснованих на мистецтві, практичному досвіді, експертних оцінках і дорогих експериментальних перевірках якості функціонування цих моделей. Крім того, в процесі створення і функціонування BIM суттєві зміни чи уточнення інформаційних потреб учасників користувачів ще білыше ускладнює супровід інвестиційно-будівельних проектів із застосуванням технології інформаційного моделювання комплексу будов/об'єктів будови -BIM.

\section{Проектування. Класифікатори.}

Перш за все, слід зазначити, що сучасне проектування - це, здебільшого, колективна праця, де процеси результативного співробітництва групи людей самі по собі важкі, тривалі за часом і конфліктні, тому що потребують вибудовування схем взаємодії, розподілу ролей, обов'язків і контролю за якістю та виконання. Що робить неприйнятними поспішні (i насильницькі) спроби впровадження BIM відразу на всіх рівнях, які, як правило, приводять до зниження якості і збільшення термінів проектування. Тому, на найперших етапах переходу до технологій, слід поміняти акценти і задуматися не стільки про глобальні переваги, скільки про його практичне впровадження. Тому питання "Як впровадити BIM технології", можливо замінити на - "Які елементи BIM технологій ми здатні використовувати з максимальною ефективністю прямо зараз?".

Тепер про класифікатори і їх ролі при впровадженні та використанні BIM. Згадаємо, що:

- ВIM - технологія об'єктно-орієнтована, тому при створенні моделі ключову роль відіграють базові (бібліотечні) елементи, що представляють певні елементи будівлі;

- ці бібліотечні елементи містять певну інформацію про відповідні будівельні елементи, яка може знадобитися як зараз, так і для подальшої або повного пророблення (аналізу) проекту (моделі будівлі).

Характерний приклад, який дає розуміння першочергового значення класифікаторів та бібліотек: кожен будівельний елемент має вартість, а крім того, $€$ вартість його монтажу, значення яких можуть абсолютно не цікавити проектувальника, який розміщує цей елемент в моделі, але які дуже важливі для кошторисника і будівельника. Тоді питання: звідки у елемента, поміщеного в модель, візьмуться значення вартості і вартості його монтажу?

Перший "традиційний і найпростіший" варіант відповіді: кошторисник, отримавши модель від проектувальника, привласнює всім іiі елементам відпо- 
відні значення. Але це шлях довгий, важко контрольований і постійно приводить до людських помилок.

Другий, на вигляд "більш складний", але в підсумку найпростіший і ефективний при роботі варіант: всі значення вартості і вартості монтажу введені в бібліотечні елементи заздалегідь, так що вони виявляються в моделі відразу після вставки елемента, образно кажучи, "поза волею проектувальника". Звичайно, такий варіант передбачає, що вже мається заздалегідь створений класифікатор будівельних елементів у вигляді бібліотеки для інформаційного моделювання.

Такий класифікатор можна створити для

1) організації, великої,

2) вертикально інтегрованої компанії (холдингу) або

3) всієї країни.

Останній варіант є найкращим, оскільки:

- уніфікує всі будівельні проекти в масштабах держави і робить їх більш доступними для аналізу, контролю та спільного використання;

- створення для всієї країни класифікатора будівельних елементів є необхідною складовою частиною державної стандартизації будівельної галузі

- такий класифікатор має особливо важливе значення, якщо ставити питання про впровадження BIM в масштабах цілої країни.

На практиці використання класифікатора при інформаційному моделюванні будівель виглядає дуже просто: елемент, який вставляється в модель, має у властивостях код за класифікатором та інші подібні характеристики, за якими потім можна вести специфікування. Можливість вводити такі значення передбачена практично у всіх сучасних BIM програмах.

Отже, питання створення для всієї країни класифікатора будівельних елементів має вирішуватися державою у дуже короткий термін.

Обмін інформацією в ВIM середовищі - проблема інтероперабельності.

В інформаційних системах однією з головних проблем є обмін даними між різними підсистемами, незалежно від рівня управління будівництвом, особливо їх здатність (двох або більше систем або компонентів) до обміну інформацією і використання цієї інформації. Тобто на лице, проблема інтероперабельності, яку ми ще звемо "проблемою перекладача". Що це означає на практиці: компанії-розробники програмного забезпечення, яких ми згадували раніше, базують моделі даних будівлі на основі оригінальних платформ в CAD, які мають свої внутрішні структури даних в "форматі замовника". Це означає, що вони не можуть обмінюватися інформацією один 3 одним, якщо для того немає так званого "перекладача" - стандарта для обміну даними. Тому:

- ВIM-співтовариство розробило специфікації (формату даних) з метою визначення стандартів для загального уявлення і обміну, шляхом створення формату даних із відкритою специфікацією IFC (Industry Foundation Classes), який використовується як формат для інформаційної моделі будівлі (Building Information Modeling) i

- IFC був розроблений для того, щоб створити велику групу несуперечливих даних, здатних представляти собою модель даних будівлі, дозволяючи, тим самим, обмін інформацією між різними виробн- иками програмного забезпечення в галузі архітектурного та технічного проектування і будівництва.

- IFC проявляється в якості моделі даних перекладу, в форматі, який "нікому не належить", доступному для визначення об'єктів в сфері архітектурного і технічного проектування і будівництва. Тим не менш, це не стандартизує структури даних в програмних додатках, і обмежується лише стандартизацією спільно використовуваної інформації.

- IFC - схема даних, яка дозволяє зберігання даних і обмін інформацією між різними додатками BIM, і яка, в той же час, розширюється і має інформацію, що охоплює безліч дисциплін, які вносять вклад в будівлю протягом iï життєвого циклу з моменту розробки концепції, проектування, будівництва, до реконструкції або знесення.

- Формат файлу був розроблений buildingSMART (International Alliance for Interoperability, IAI) для спрощення взаємодії в будівельній індустрії. Не контролюється жодною компанією або групою компаній.

\section{ВIM-менеджери.}

Багато що залежить від досвіду і націленості компанії на те, щоб освоїти програму. Природно, з'являються такі окремі посади, як BIM-менеджери. I якщо подивитися на успішні компанії, які працюють в BIM, то BIM-менеджер - це окрема одиниця, яка нічим більше не займається, крім координації роботи, створює необхідні бази для роботи і т.д. Основна проблема - це те, що не напрацьовані бази, сімейства виробів, більшу частину яких на початковому етапі доводилося створювати 3 нуля. Коли ці бази напрацьовуються, то, звичайно, процеси прискорюються і автоматизуються. За уявленнями фахівців, впровадження ВIM займає кілька років, в залежності від кількості людей в компанії:

- це координація внутрішньої роботи в одному середовищі, в одній інформаційній моделі, інші правила роботи. Я б не сказав, що в Росії є проблеми $з$ $\mathrm{BIM}$ - є проблеми його впровадження

- це вимагає всіх учасників проекту дисципліни, формування досить жорстких внутрішніх корпоративних стандартів роботи з програмою.

Вихід за рамки проектної організаціі.

Інформатизація будівництва дозволяє сьогодні вирішувати завдання, які раніше вирішити було неможливо. ВІМ-технології дають можливість проектувати ефективніше, якісніше, і більш точно управляти ризиками. Більш точним стало прогнозування витрат на будівництво.

На етапі планування будівництва можливо синхронізувати віртуальні моделі з графіком робіт,

За допомогою віртуальної моделі:

- кожен елемент тривимірної моделі отримує додаткову інформацію про той час, коли він буде будуватися;

- модель дозволяє проаналізувати створений графік і визначити помилки в їх логічній послідовності;

- розробка такого сценарію також дає можливість отримати аналітичні довідки за потребою матеріалів, по завантаженню кранів і доставці ресурсів на будівельний об'єкт;

- контролюються терміни виконання робіт;

- крім того, фахівці з охорони праці використо- 
вують цифрову модель для збору інформації та оцінки рівня безпеки будівельних майданчиків.

Вже штатними можливостями багатьох сучасних програмних комплексів, таких як Revit, Tekla Trimble, Allplan, Navisworks, Archicad, Vectorworks, RhinoBIM (McNeel), formZ (Autodessys), ArchLineXP(CadLine), SCIA, Graitec та інших можливо, зокрема, сформувати наочну послідовність комплексів будівельних робіт і добре спланувати графік їх віконання, поеднуючи з логістикою, матеріально-технічним забезпеченням, контролем їх якості, вартості і виконання. Такий підхід ще називають 4D-5D моделюванням (проектуванням).

Крім того, ряд функцій авторського нагляду в будівництві тепер можна робити віддалено за допомогою програмного забезпечення.

\section{Експлуатації об'єкту.}

BIM модель - це компактний цифровий архів знань по об'єкту, з необмеженим терміном зберігання і можливістю повторного використання проектної документації по об'єкту експлуатації.

- технологія створює інструмент оперативного і точного розрахунку витратних матеріалів для поточного або сезонного ремонту, а всі знання накопичуються в централізованому сховищі;

- таким чином, це інструмент оперативного прийняття рішення і скорочення часу з пошуком потрібної інформації.

\section{Невідповідності, помилки.}

Особливістю CAD проектування є збір розрізнених фактів про об'єкт окремо один від одного, що призводить до неузгоджень, невідповідностей i помилок.

Інформаційне моделювання ж дозволяє здійснювати збір інформації в єдиній системі, що виключає невідповідності.

В форматі електронної моделі експерти значно швидше перевіряють проектні рішення.

Працюючи з BIM, експерт набагато оперативніше може знайти потрібну деталь, відстежити відповідність конструктивних, архітектурних, об'ємно-планувальних, технологічних та інших проектних рішень нормам техрегламентів. Тобто в глобальному сенсі - це зручніше і ефективніше.

Отже, дана технологія дозволила скоротити кількість виникаючих помилок в рази, що відповідно в стільки ж скоротило кількість різного роду доробок. Важливо також звернути увагу на скорочення часу проектування, що в свою чергу, дозволяє істотно економити на грошових витратах, і таким чином, підвищується рівень продуктивності організації, що в кінцевому результаті дає змогу підвищити виплати співробітникам і збільшити загальний прибуток.

\section{Складнощі в роботі з ВIM}

Найгостріший момент - це різний рівень впровадження BIM у всіх залучених в інвестиційно-будівельний проект компаній:

- відсутність регламентів електронного документообігу та загального стандарту передачі даних по проекту ускладнює процедуру обміну інформацією

- доходить до того, що фахівці команди управління проектом, приймаючи від когось із суміжників розділ, в прямому сенсі, на кальці змушені самі вручну переносити його в інформаційну модель. Часто, навіть на стадії реалізації проекту, доводиться вести різноманітне моделювання і актуалізувати кілька варіантів моделі одночасно. У підсумку на дуже складних проектах мають місце програмні і ресурсні обмеження, що вимагає від членів команди проекту:

- працювати з різними форматами файлів і моделей і конвертувати вихідні дані в свої моделі;

- знаходити рішення для обходу програмних і ресурсних обмежень і поступово вдосконалюватися в цьому.

\section{Висновок.}

Будівельні компанії усвідомлюють, що з часом їх основні конкуренти перейдуть на ВIM-моделювання, тому необхідно шукати рішення проблем при впровадженні технологій в кожну конкретну організацію для того, щоб в майбутньому залишитися на ринку.

Основні проблеми, що виникають при впровадженні BIM:

- високі початкові витрати, оскільки впровадження BIM - це процес системних змін, чий суперефект відкладений у часі;

- дороге програмне забезпечення - необхідно закупити потужні комп'ютери, програми і ліцензї̈ на ПЗ, оновлення робочих станцій інженерів-проектувальників, створення нової серверної та мережевої інфраструктури, створення відділів BIM-менеджерів, навчання кваліфікованих фахівців.

- неадаптована (некоректна) робота програмних комплексів - щоб працювати в інформаційній моделі у архітекторів, конструкторів, проектувальників повинні бути напрацьовані бази - бібліотеки сімейств продуктів. Водночас все це розкриває безліч інших проблем в організації процесів. 3 огляду на іноземне коріння програмного забезпечення, не все адаптовано під норми і ДСТУ України;

- брак фахівців в області ВІМ-моделювання далеко не у всіх вітчизняних вузах цьому вчать, а систематично - ніде в Україні.

Важливі також терміни і технологічний процес впровадження, зміна бізнес-процесів компанії, написання регламентів розробки та роботи 3 моделлю, організація структури зберігання елементів і компонентів моделі, методика внесення змін і позначок; відрив від основного виробництва. Перераховані вище пункти - недоліки технології інформаційного моделювання. Процес переходу дорогий і розтягнутий у часі. Реальні дивіденди використання технології BIM починає приносити через два-три роки.

Але найголовнішою проблемою впровадження технології інформаційного моделювання залишається відсутність розуміння кінцевої мети використання цієї технології.

Для часткового або повного вирішення перерахованих вище проблем можна запропонувати деякі кроки:

- по-перше, будівельні компанії можуть вкладати кошти в навчання персоналу, вже зарахованого до штату компанії, або в освіту студентів з метою подальшого їх залучення до роботи в даній організації. Таким чином, можна самим "виростити" майбутніх фахівців;

- по-друге, невеликі проектні організації, що не володіють необхідним резервом, можуть об'єднатися для подальшої співпраці, обміну досвідом, а також для можливості спільної покупки програмного забезпечення. 


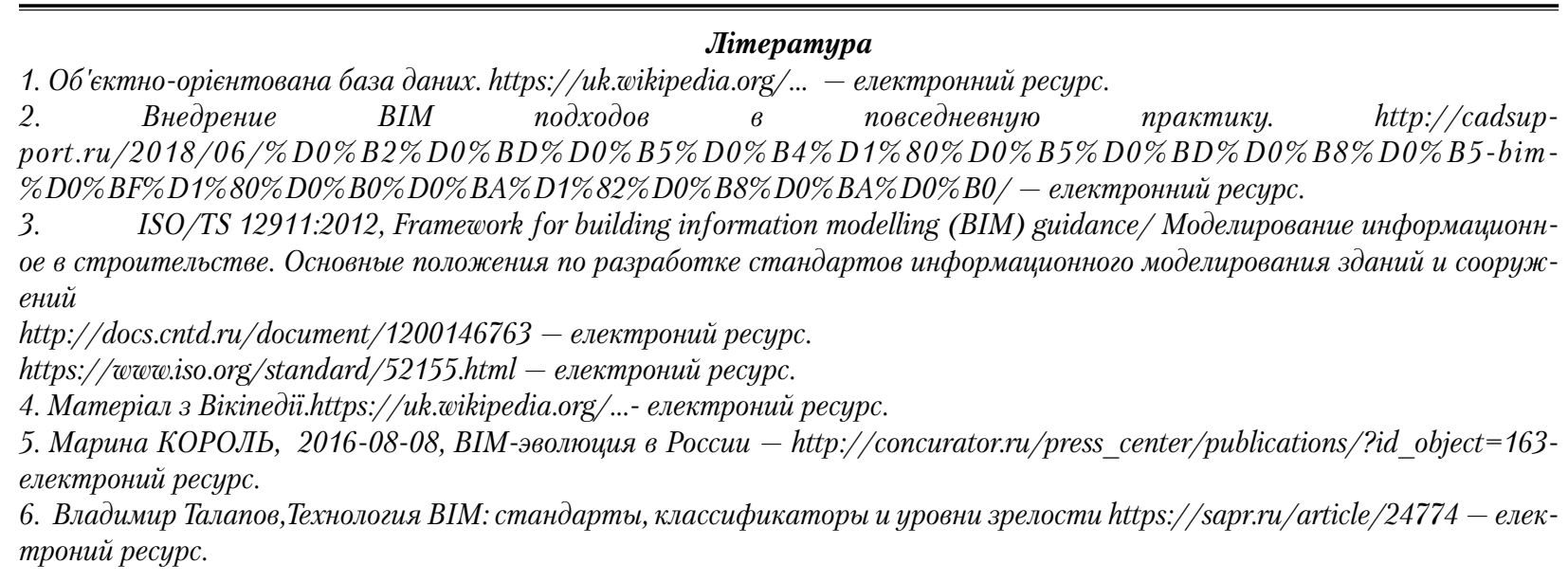

Reference

1. Ob'Ektno-orIEntovana baza danih. https://uk.wikipedia.org/... - elektronniy resurs.

2. Vnedrenie BIM podhodov v pozsednevnuyu praktiku. http://cadsupport.ru/2018/06/vnedrenie-bim-praktika/ - elektronniy resurs.

3. ISO/TS 12911:2012, Framework for building information modelling (BIM) guidance/ Modelirovanie informatsionnoe v stroitelstve. Osnovnyie polozheniya po razrabotke standartov informatsionnogo modelirovaniya zdaniy i sooruzheniy

http://docs.cntd.ru/document/1200146763 - elektroniy resurs.

https://wrow.iso.org/standard/52155.html - elektroniy resurs.

4. MaterIal z VIkIpedIYi.https://uk.wikipedia.org/...- elektroniy resurs.

5. Marina KOROL?, 2016-08-08, BIM-evolyutsiya v Rossii - http://concurator.ru/press_center/publications/?id_object=163elektroniy resurs.

6. Vladimir Talapov,Tehnologiya BIM: standartyi, klassifikatoryi i urovni zrelosti https://sapr.ru/article/24774 - elektroniy resurs.

О.Ю. Чертков, к.т.Н., доц;. В.А. Цегельный; Д.С. Ермолович

КНУСА, г. Киев

\title{
ОСОБЕННОСТИ ИСПОЛЬЗОВАНИЯ ВІМ-ТЕХНОЛОГИИ В ОТЕЧЕСТВЕННЫХ КОМПАНИЯХ В УСЛОВИЯХ ОТСУТСТВИЯ НАЦИОНАЛЬНЫХ СТАНДАРТОВ ИНФОРМАЦИОННОГО МОДЕЛИРОВАНИЯ ЗДАНИЙ- ВІМ
}

\begin{abstract}
Аннотация. Несмотря на высокие потенциальные возможности ВІМ-технологии (увеличение производительности труда, улучшение качества задокументированной информачии, поддержка унифицированного и согласованного стиля работы) далеко не все участники, использующие методику информационного моделирования, достигают ожидаемых результатов. Существуют различные причины возможных неудач, но, видимо, основной причиной является неадекватное понимание сути интегрирующей работы информационных систем и применения ВIM-средств.

Ключевые слова: Информачионное моделирование, ВІМ, ВІМ-стандарты, ВІМ-технология, жизненный цикл, строительный проект, проектирование, моделирование, строительство, эксплуатащия, документированная информация.
\end{abstract}

O.Y. Chertkov; V.O.Tsehelnyi; D.S. Ermolovich

Kyiv National University of Civil Engineering and Architecture, Kyiv

\section{FEATURES OF THE USE OF BIM TECHNOLOGY IN DOMESTIC COMPANIES IN THE ABSENCE OF NATIONAL STANDARDS FOR INFORMATION MODELING OF BUILDINGS - BIM}

\begin{abstract}
Despite the high potentialities of BIM technology (increased productivity, improved quality of documented information, support for a unified and consistent work style), not all participants using information modeling techniques achieve the expected results. There are various reasons for possible failures, but apparently the main reason is an inadequate understanding of the essence of integrating information systems and the use of BIM tools.

Key words: information modeling, BIM, BIM standards, BIM technology, life cycle, construction project, design, modeling, construction, operation, documented information.
\end{abstract}

